THE SKIN OF THE SYSTEM 



\section{The Skin of the System}

ON GERMANY'S SOCIALIST MODERNITY

Benjamin Robinson

STANFORD UNIVERSITY PRESS

Stanford, California 2009 
Stanford University Press

Stanford, California

(C) 2009 by the Board of Trustees of the

Leland Stanford Junior University

All rights reserved

No part of this book may be reproduced or transmitted in any form or by any means, electronic or mechanical, including photocopying and recording, or in any information storage or retrieval system without the prior written permission of Stanford University Press.

Library of Congress Cataloging-in-Publication Data

Robinson, Benjamin.

The skin of the system : on Germany's socialist modernity /

Benjamin Robinson.

p. $\mathrm{cm}$.

Includes bibliographical references and index.

ISBN 978-0-8047-6247-2 (cloth : alk. paper)

I. Fühmann, Franz-Criticism and interpretation. 2. Socialism and literature-Germany (East). 3. Socialism-Germany (East). I. Title.

PT26II.U436R63 2009

$838^{\prime}$ 9I409-dc22

2009007179

Printed in the United States of America

on acid-free, archival-quality paper

Typeset at Stanford University Press in Io/13 Galliard 